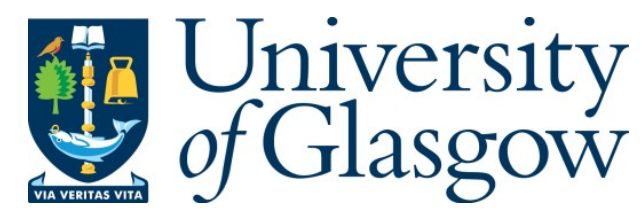

Siebert, S., and Wilson, F. (2013) All work and no pay: consequences of unpaid work experience in the creative industries. Work, Employment and Society, 27 (4). pp. 711-721. ISSN 0950-0170

Copyright $\odot 2013$ Sage

A copy can be downloaded for personal non-commercial research or study, without prior permission or charge

Content must not be changed in any way or reproduced in any format or medium without the formal permission of the copyright holder(s)

When referring to this work, full bibliographic details must be given

http://eprints.gla.ac.uk/70008/

Deposited on: 06 M arch 2014

Enlighten - Research publications by members of the University of Glasgow http://eprints.gla.ac.uk 


\title{
All work and no pay: Consequences of unpaid work in the creative industries
}

\author{
Sabina Siebert and Fiona Wilson
}

\begin{abstract}
This research note evaluates the benefits and pitfalls of unpaid work as an entry route into employment in the creative industries, and investigates the consequences of this practice for those who already work in the sector. Based on a qualitative study of perspectives of stakeholders in unpaid work, this article argues that social capital thesis (Coleman 1988) often used as a rationale for unpaid work, inadequately explains the practice of unpaid work experience, primarily because it does not take cognisance of the consequences of this practice for other people working in the sector. The study also highlights methodological issues that need to be considered in the future. As well as the importance of a plurality of stakeholder perspectives, the study emphasises the need for considering the perspectives of those who are excluded from unpaid work, and those who are potentially displaced by it.
\end{abstract}

\section{Introduction}

The unemployment rate for new graduates is at its highest in over a decade (ONS, 2011). There is also a stark warning that graduates without work experience "won't find a job" (Coughlan, 2012). Recruiters say that one third of entry level jobs for graduated are expected to be filled by those who have already worked for their organization (High Flyers Research, 2011). The number of internships on offer has risen to around a quarter of a million (Lawton and Potter, 2010). It is not surprising then that students seek work experience during their time at university. Jobs in the UK's creative industries sector are popular, high value and appear glamorous. The creative industries sector employ around a half a million people in the UK and has grown at an average of 5 percent per annum compared to an average of 3 percent per annum across the economy as a whole; it is expected to grow at 4 per cent per annum between 2008 and 2013 providing 150,000 jobs over the next three years (Shorthouse, 2010). However unpaid work is often the only route into the sector. Previous studies suggest that the incidence of young people undertaking unpaid work in the creative industries is high and growing. For example between 2005 and 2008 the proportion of the creative economy workforce reporting having done unpaid work grew from 38 to 45 percent (Skillset, 2008). Ball et al. (2010a) found that 42 percent of graduates from the creative sector have been undertaking voluntary work since graduating. Around $3 / 4$ of photographers, 58 percent of radio freelancers, and nearly half of the TV workforce have undertaken unpaid work in their sector (Skillset, 2010). They do so in the hope of securing a permanent job. Unpaid labour benefits the business, and when the demand for work experience is high, employers are able to use unpaid labour as 'a cost-effective flexible solution to recruitment needs' (National Council for Work Experience, 2011). A 'try before you buy' approach, means that the graduate is 'getting a taste' of the industry, while the employers are getting a chance to 'test' the candidate.

Work in the creative industries however is becoming increasingly uncertain and competitive (Townley and Beech, 2010; Antcliff et al. 2007). Despite the benefits of "flexible" work, 
there are pitfalls. There is evidence that lower-skilled workers are being displaced (Hofman and Steijn, 2003). A number of critics have also discussed the exploitation of some creative workers who are 'seduced into putting a great deal of themselves into what they do' (Hesmondhalgh, 2010: 282). The Low Pay Commission (2011) is concerned that an increasing number of employers are ignoring the minimum wage rule by hiring interns to undertake unpaid work. Non standard employment increases workers exposure to "bad jobs" (McGovern et al, 2004). For many people periods of unemployment are interspersed with paid work, and 'slack times' may lead to abandoning the efforts to remain in the sector (Ball et. al. 2010b). Also, a lack of career structure to support progression means that people, particularly women, leave the sector unable to establish a secure and regular pattern of employment (Skillset, 2010). The precarious nature of work in this sector (Hesmondhalgh and Baker, 2010) may be a source of significant disadvantage for some sections of society (McRobbie, 1998). The employment profile in this sector demonstrates a limited social and ethnic diversity of the workforce. For example only 6 percent of the creative industry workforce is from a Black, Minority and Ethnic background compared to 9 percent across the whole workforce (Shorthouse, 2010). The lack of diversity is often attributed to the industry's reliance on networks. Those who benefit from networks find that they foster collaboration, leading to economic advantage in the labour market. This economic advantage, otherwise expressed as economic rationality (Townley and Beech, 2010) is linked to individuals gaining access to information about employment opportunities (Lee, 2011). Forming and maintaining professional contacts, networks has been found to be crucial in recruitment and selection in the creative industries, but it is also important in career development and knowledge sharing for individuals already in the sector (Daskalaki, 2010). The value of network ties has often been conceptualised as social capital (Antcliff et al. 2007; Bourdieu, 1983; Vershinina et al. 2011). Because of the 'social mechanisms' of allocation of work in the creative industries (Baumann, 2002) access to networks, may advantage some individuals, or cause social exclusion of those who do not have this access (Oakley, 2006).

Coleman (1988) distinguishes between three forms of social capital. The first form, obligations, expectations and trustworthiness of structures, is based on mutuality and reciprocity, and an understanding that 'obligations will be repaid, and the actual extent of obligations held' (1988: 102). The second form of social capital is about providing information held and distributed by network members that facilitates action, as well as trust in this information. The third form, norms and effective sanctions, indicates that ties guarantee the observable norms, for example the norm that an individual should forego self-interest and act in the interest of the collective. Effective norms, according to Coleman, constitute a powerful form of social capital.

Unpaid work in the creative industries allows people to acquire the social capital needed to find employment. However there is a dearth of studies on the experience of acquiring social capital through unpaid work as an entry route into employment. There is also no research on the experience of those who work with the unpaid. This research note reports on initial exploratory fieldwork on unpaid work, evaluating the benefits and pitfalls of unpaid work as an entry route into employment in the creative industries, and investigates the consequences of this practice. Drawing on a qualitative study of a range of stakeholder perspectives in the practice of unpaid work as an entry route into employment, this research note evaluates how well social capital theory (Coleman, 1988) explains the practice of unpaid work experience. This study draws on a plurality of perspectives. 


\section{Methodology}

This mixed-method study based on an interpretative perspective was carried out in three stages. In the first stage, a policy analysis was carried out to identify the key issues in relation to unpaid work experience. The documents analysed ranged from higher education reports (e.g. Universities UK, 2010), to sector skills council reports (e.g. Skillset 2008; 2010). The documents were analysed twice - first, a bottom-up approach was used to identify the key themes in relation to unpaid work; and second, to confirm specific evidence about the key themes.

The second stage involved a survey of students and recent graduates aspiring to secure a career in the creative industries. The main criterion for inclusion in the survey was participation in unpaid work experience. The sample included students and graduates of undergraduate degree programmes in media studies, multi-media journalism, theatre studies, events management, and history of art from two universities in the UK. Students with unpaid work experience were identified from class lists and invited to take part, as well as recent graduates who remained in contact with the teaching teams. 71 respondents took part including 52 females and 19 males representing a response rate of 72 percent (this high response rate can be attributed to the questionnaire being distributed in a classroom setting). All respondents were normally based in UK regions other than London, where there is the highest concentration of creative industry organizations. Respondents' age ranged from 20 to 31. The percentages used in the analysis refer to the whole sample without making a distinction between specific sectors, and between those who have and those who have not found paid employment. The third stage comprised 22 in-depth interviews with stakeholders: students and recent graduates from four universities in the UK who had experience of work placements in the creative industries (6), representatives of student bodies including National Union of Students and other local associations (3), university staff (lecturers (4), career advisors (2), a placement officer (1) and a work placement manager (1)), representatives of trade unions for the sector (4) (NUJ, BECTU and Equity), and a pressure groups promoting fair access to the internship system (1). A snowball sampling technique was used in identifying respondents. Interviews lasted from 25 minutes to one hour, were subsequently transcribed, coded and analysed thematically. Students and graduates who participated in unpaid work experience are referred to as 'participants in work experience', whereas the term 'workers' refers to paid individuals in the workforce.

The consequences of unpaid work as an entry route into employment are evaluated differently by different stakeholders. Three main themes emerged from the data: fairness of unpaid work, its impact on social mobility and its impact on other stakeholders in the industry. The analysis of findings was carried out within the framework of these themes.

\section{Fairness of unpaid work}

The issue of unpaid internships has been the subject of many political debates, and, unsurprisingly, it emerged strongly in the interview data. The main argument made by trade unions and student bodies is that unpaid work experience leads to a situation where those who cannot afford to work for free are excluded from work experience, and consequently, excluded from acquiring the social capital needed to succeed in the sector. Notwithstanding the issue of legality of unpaid work in light of the 1998 minimum wage legislation, various stakeholders expressed concerns about the exploitative nature of the practice. Trade unions vehemently opposed the practice of long-term, unregulated and unpaid work, and warned that young people who are attracted to the glamour of the creative industries are at risk of 
exploitation. The drive to be creative makes people less sensitive to exploitation of unpaid work, and such work, according to the trade unions is both damaging and illegal. The duration of unpaid work is also of concern. In the past, unpaid work may have lasted for a few weeks, but now it is reported to last as long as six or even 18 months, and is sometimes used as a replacement for temporary contracts. The trade union respondents, as well as the campaigner interviewed, reported on successful legal cases pursued against employers abusing unpaid workers.

Although a significant proportion of participants' in the questionnaire (59 percent) agreed that unpaid work is exploitative, many still believed that 'this is how things are' and work experience was crucial in gaining employment (for example noting 'I don't know of anyone who's got a job without going on voluntary work placement'). Despite the majority of respondents claiming the work experience opportunities were exploitative, 71 percent were still happy to recommend their employers to others, and saw unpaid work as the legitimate way to find work.

For the participants in work experience benefits were offset by pitfalls. On the one hand, they valued an opportunity to consider career options, acquired technical and transferable skills, and built self-esteem. Reflecting on the experiences of work, participants appeared to have learned from being given responsibility for discrete tasks, valued hands-on experience, and enjoyed working alongside more experienced staff. On the other hand, these benefits came at a cost, having to do unpaid work. Students and graduates were prepared to work up to a thousand hours for free to 'ingratiate themselves with the industry', 'get their face noticed', or "get ahead". The work experience did not always deliver the benefits anticipated. Both the interviewees and survey respondents expressed dissatisfaction at the repetitive character of the work, 'being treated as a dogsbody', and getting very few opportunities to engage in complex tasks. The concern was that some employers did not provide unpaid workers with experience of real creative work, and students saw themselves as being given irrelevant jobs, which destroyed their interest.

The promise of paid employment after a period of unpaid work in the creative industries was often the main motivator. However, a question arose as to whether a period of unpaid work delivered on the promise of a paid job. One trade union respondent said: 'There's an unwritten implication that if you stick with us and if you work hard you'll learn, and then if something comes up we will give you first shout'. The findings from students and graduates support this sentiment. Despite the drawbacks and the high costs associated with working for free, the majority of participants believed that they would acquire access to information channels and the 'right people' who would promise them a job. When asked about the fulfilment of that promise, the survey data indicated that for only 45 percent respondents, work experience led to paid work. Despite a lack of success, most respondents demonstrated tenacity to continue working for free. There appeared to be a tacit agreement amongst those who undertake unpaid work that it is necessary for gaining employment, one participant saying "If I really tried to make more opportunities, then yes, it would lead to paid employment eventually". Another respondent noted: "you are going to have to work for either really, really low pay, or for free for a long time before you are recognised as being someone who is reliable."

Referring to Coleman's classification, the industry appears to impose an obligation and expectation of unpaid work, which brings benefits for the business and offers a cost-effective solution to recruitment needs, but does not always offer the rewards of a job. Further, over 
half of participants surveyed did not receive reimbursement of expenses or any benefits in kind. When questioned about how they provided for themselves while undertaking unpaid work, they acknowledged support from parents, and drawing on savings from paid jobs in other sectors. One respondent mentioned spending her inheritance money in order to be able to live and work for free in London.

\section{Impact on social mobility}

Trade unionists and student bodies expressed their concern that an oversupply of candidates competing for a limited number of openings in this sector led to a situation where available positions went to 'those with the right connections'. In their view, the introduction of the requirement on the employers to pay for work experience would not address the issues of social mobility. It is not only the lack of economic capital that prevents people from undertaking work experience, but also their lack of social networks. The challenges in accessing work experience could be traced back to the lack of individual's social capital, thus putting some sections of society at a disadvantage, and creating access barriers for those without the required social, economic and cultural capital. This lack of social capital also prevented individuals from accessing work experience, let alone paid employment. Underprivileged people do not have the appropriate connections to find paid jobs, and they cannot afford to work for free to get their 'foot in the door'. As much as getting a job in the creative sector depends on having the right connections, securing relevant work experience depends on having these connections as well. This becomes a vicious circle - to gain information channels in the industry, one needs to have access to work experience, but getting access to work experience depends on having information channels in the industry. The 'social mechanism' of sourcing employment is inevitably exclusionary, and means that upward social mobility in this sector may be hindered, existing inequalities reinforced, and social diversity of the workforce undermined.

While the participants in unpaid work were aware of the geographic and information factors, a concern for social inequality in access to work experience was less evident in responses from students and graduates. It was mainly other stakeholders, such as career advisors or trade unions who commented on this issue.

\section{Impact on other stakeholders}

The literature on work experience advocates benefits of work placements (e.g. Ball, et al. 2010a) - individuals are said to acquire social capital which will later allow them to succeed in the world of work, and the employers are said to benefit from the fresh talent, knowledge of technology, enthusiasm and access to the pool of future recruits. However, the data collected here indicated that the widespread practice of unpaid work had a significant impact on those already working in the sector. One trade union respondent said that unpaid work 'undermines everyone as it creates this attitude that that's all they are - cheap labour and there is no value attached to their work'. Because some people volunteer to work for free, others 'do not get the proper rate' - one trade union official observed. This 'dog eats dog' situation erodes trust between people in the workplace and new recruits of the future. Another trade union official commented that 'the cheaper you make it, then the more other employers try to compete, and if it was allowed to run out of control, it would be entirely voluntary sector'. Unpaid staff were often seen to fill in long-term staffing gaps, cover periods of maternity leave, and conduct tasks that fully paid workers would normally be expected to perform. The depressed labour market, according to the respondents, leads to redundancies and replacing of temporary contracts with unpaid staff. 
Tensions between staff and interns arose when work experience 'got out of control' and the terms under which individuals were in the organization were not communicated to staff. Also, what gave rise to tensions was the requirement on existing staff to supervise unpaid staff. The trade union interviewees argued that when not trained and supervised properly, unpaid staff produced poor quality work, which in turn had an adverse effect on the quality of the product, creating more work for others responsible for making corrections. They also stated that inadequate training triggered a range of health and safety issues, such as putting inexperienced staff in danger during journalistic fieldwork.

In addition the data suggest that people who complain about lack of pay quickly become unemployable. One trade union official said: 'I can show you cases where there's people who have never worked in the [TV Company] again after raising a complaint'. This creates a culture where the fear of victimisation in the labour market normalises the expectation of unpaid work. This suggests that acquisition of social capital, which underpins the expectation of unpaid labour, is problematic from the point of view of building trust among individuals. Participants in unpaid work did not comment extensively on the consequences of their presence on other people in the workplace, though this is not to say they were not aware of it. Many respondents mentioned tensions arising from less than friendly attitudes of staff, a lack of interest in their learning, and unwillingness to engage them in meaningful work. Colleagues who are unhelpful in the workplace are unlikely to help with providing information on new openings. Coleman's second form of social capital, which refers to information channels as well as trust in this information, is not evident in this context.

\section{Discussion and conclusions}

A number of points emerge from the analysis of the empirical data. Firstly, focusing only on the benefits of unpaid work experience for an individual ignores the wider context of the practice, and the impact that this practice has on the sector. Secondly, analysing the stakeholders' perspectives through Coleman's theoretical lens identifies tensions between individualistic and social accounts of the practice of unpaid work. Thirdly, a question arises whether an individual who exercises his/her own freedom and willingly takes on work without pay should be allowed to do so; are individuals free to be exploited, particularly when this impacts on others? Finally, at first sight, the polarisation of the experiences of the paid and unpaid workers resonates with the classic accounts of dual labour market theory offered by Doeringer and Piore (1971). However, the analysis of the data problematizes this conceptualisation of a labour market. Instead, it supports later developments in labour market segmentation theory (Grimshaw and Rubery, 1998; Grimshaw et al., 2001) which highlighted the interrelationship between the primary and secondary sectors, and called for a more nuanced and dynamic conceptions of dual labour markets. Both paid and unpaid jobs exist within the same sector, albeit unpaid jobs are subject to secondary labour market conditions. Individuals who can afford to do unpaid jobs will do so on the expectation that they ensure the growth of their social capital, which they can subsequently draw on to advance into paid jobs, hence there is possibility of movement from primary to secondary jobs. However, it should be remembered that many people will be excluded from unpaid work, and consequently will have limited opportunities of working in the creative sector.

These discussions are important in raising awareness of the insecurity and precariousness of work in this sector (Siebert and Moxen, 2011). However, it has to be remembered that exploitation is a complex concept, and the nature of exploitation is that individuals may not perceive what is happening to them as exploitation; hence, they are unlikely to raise it as an 
issue. The respondents' acceptance of unpaid work as 'the way things are' clearly demonstrates the methodological difficulty in researching exploitation. The social mechanisms by which work opportunities are allocated and accepted by individuals as the natural order of things only serves to hinder social mobility. Networks advantage some but exclude others from unpaid work. This article argues that the focus of the discussion on unpaid work experience as an entry route into employment needs to be broadened to consider its impact on relations between workers in the sector. Social capital theory throws some light on the process of exclusion, but does not fully explain these wider issues.

Secondly, Coleman's emphasis on obligations, expectations and trustworthiness of structures is crucial in the discussion as it reveals that the industry appears to impose an expectation of unpaid work, but does not always offer economic and social benefits for individuals in return. Reciprocity and mutuality inherent in the first form of social capital are lacking, which affects the trustworthiness of the arrangement. So an understanding that 'obligations will be repaid, and the actual extent of obligations held' (Coleman, 1988: 102) is unfounded, if for more than half of participants in unpaid work the promise of a paid job is false. Social capital, according to Coleman, is based on trust among individuals. The empirical evidence collected here suggests erosion of trust between unpaid workers motivated by a desire to enter the industry, freelance workers already in the sector and the employers. This erosion of trust and tensions arising between paid and unpaid workers broadly echo Greary's (1992) comments on animosity between temporary and permanent employees, Byoung-Hoon and Frenkel's (2004) research on moral exclusion of contract workers by regular workers, and the potential displacement of lower skilled workers by unpaid ones. The data collected here demonstrate that the practice of unpaid work may have similar negative consequences for the relations in the workplace, and point to a weakness in the social capital thesis used as a rationale for unpaid work experience as an entry into employment.

Grugulis and Stoyanova's (2011) findings indicate that due to the fragmented labour market in the cultural industries, the separation between novices and freelance experts negatively impacts on learning and skills development. This study highlights another form of separation, namely the issue of perceived illegitimacy of novices who pose a threat to those already in the workplace. This separation does not only affect learning, but also hinders harmonious relations between workers. However, the argument expressed by the opponents of unpaid labour as an entry into employment has to be counterbalanced by a duty of care for young people starting their careers. Putting an end to the practice of work experience should not be seen as pulling a rug from under people's feet, and making it even more difficult for them to gain employment. Providing work experience opportunities with due consideration for harmonious relations in the workplace might be an answer to the dilemma - this may involve pay, transparent recruitment and selection, and consultation with work councils or trade unions. Thus for example, the interviewees pointed to existing work experience schemes designed with these considerations in mind (The BBC work experience scheme being frequently cited).

Two methodological issues arise from the design of this study and have implications for future research agendas. The plurality of perspectives underpinning the study revealed the tensions between individual and social accounts, and made it possible to evaluate the consequences (such as displacement, or erosion of trust) that the practice has on other people in the workplace. Also, this study indicates a weakness in the approach based on collecting data from participants in work experience only. There are two groups whose perspectives have not been taken into consideration here. One group is those who aspire to find work in 
the creative industries but who have been excluded from participating in unpaid work experience. If, as the data suggests, unpaid work experience is an exclusionary practice, surveying those who participate in it is missing the perspectives of the excluded. This methodological issue is even more pertinent given that participants in work experience are themselves beneficiaries of the exclusionary process of developing social capital and are often unaware of the obstacles that others encounter in sourcing work experience. The second group are people currently working in the industry, who are potentially 'displaced', and who suffer the negative consequences of unpaid work. Their views in this study are reflected in the accounts of the trade union representatives interviewed, but reaching such workers directly would inform further enquiry. These methodological observations therefore have relevance beyond this study.

\section{Acknowledgements}

Sabina Siebert would like to acknowledge the contribution made by John Moxen to the BMAF grant application and the questionnaire design.

\section{References}

Antcliff, V., Saundry, R. and Stuart, M. (2007) Networks and social capital in the UK television industry: the weakness of weak ties, Human Relations, 60: 371-393

Ball, L., Pollard, E., Stanley, N. and Oakley, J. (2010a) Creative Graduates, Creative Futures, Institute for Employment Studies

Ball, L., Pollard, E., Stanley, N. and Oakley, J. (2010b) Creative Career Stories, Institute for Employment Studies

Baumann, A. (2002) Informal labour market governance: The case of British and German media production industries. Work, Employment and Society, 16(1): 27-46.

Bourdieu P (1983) The forms of capital. In: Richardson J (ed.) The Handbook of Theory and Research for the Sociology of Education. New York: Greenwood Press, 241-258

Byoung-Hoon, L. and Frenkel, S.J. (2004) Divided workers: social relations between contract and regular workers in a Korean auto company, Work Employment and Society, 18(3):507530

Coleman, J.S. (1988) Social Capital in the Creation of Human Capital The American Journal of Sociology, Vol. 94, Supplement: Organizations and Institutions: Sociological and Economic Approaches to the Analysis of Social Structure, S95-S120.

Coughlan, S. (2012) Graduate jobs taken by work experience students, BBC News $11^{\text {th }}$ January.

Daskalaki, M. (2010) Building 'Bonds' and 'Bridges': Linking Tie Evolution and Network Identity in the Creative Industries, Organization Studies 31: 1649-1666. 
Doeringer, P.B. and Priore, M.J. (1971) Internal labour markets and manpower analysis, Lexington: Lexington Books

Greary, J.F. (1992) Employment flexibility and human resource management: the case of three American Electronic Plants, Work Employment and Society, 6(2): 251-270.

Grimshaw, D. and Rubery, J. (1998) Integrating the internal and external labour markets, Cambridge Journal of Economics, 22(2): 199-220

Grimshaw, D., Ward, K.G., Rubery, J. and Beynon, H. (2001) Organizations and the Transformation of the Internal Labour Market, Work Employment and Society, 15(2001) : $25-54$

Grugulis, I. And Stoyanova, D. (2011) The missing middle: communities of practice in a freelance labour market, Work Employment and Society, 25 (2): 342-351

Hesmondhalgh, D. (2010) User-generated content, free labour and the cultural industries Ephemera vol. 10(3/4): 267-284

Hesmondhalgh, D. and Baker, S. (2010) Creative Labour: Media Work in Three Cultural Industries, London, Routledge

High Flyers Research (2011) The Graduate Market in 2011, High Flyers Research Limited, London.

Hofman, W.H. and Steijn, A.J. (2003) Students or lower-skilled workers? Displacement at the bottom of the labour market, Higher Education, 45, 127-146.

Lawton, K. and Potter, D. (2010) Why interns need a fair wage, Institute for Public Policy Research, London.

Lee, D. (2011) Networks, cultural capital and creative labour in the British independent television industry, Media Culture Society 33(4), 549-565.

Low Pay Commission (2011) National Minimum Wage, London.

McGovern, P., Smeaton, D. and Hill, S. (2004) Bad jobs in Britain. Non-standard employment and job quality, Work and Occupations, 31, 2, 225-249.

McRobbie, A. (1998) British fashion design: rag trade or image industry? London, Routledge

National Council for Work Experience (2011) http://www.work-experience.org/ accessed 19 Feb 2011

Oakley, K. (2006) 'Include Us Out - Economic Development and Social Policy in the Creative Industries', Cultural Trends, 15(4): 255 - 273 
ONS (Office for National Statistics), (2011) Graduates in the Labour Market: Unemployed graduates double, ONS http://www.ons.gov.uk/ons/dcp171776 234888.pdf, accessed 25 March 2012

Shorthouse, R. (2010) (ed.) Disconnected: social mobility and the creative industries, London, Social Market Foundation

Siebert, S. and Moxen, J. (2011) Work Experience in the Creative and Cultural Industries: A Guide for University Staff http://www.heacademy.ac.uk/business/projects/detail/trdg/201011/trdg1011_siebert_glasgow accessed 31 July 2012

Skillset (2008) Creative Media Workforce Survey, Skillset/UK Film Council.

Skillset (2010) Labour Market Information: Creative Media Sector http://readingroom.skillsfundingagency.bis.gov.uk/sfa/nextstep $/ 1 \mathrm{mi} / \mathrm{Next} \% 20 \mathrm{Step} \% 20 \mathrm{LMI} \% 2$ 0-\%20Skillset $\% 20$ Creative $\% 20$ Media\%20Industries\%20-\%20June\%202010.pdf accessed 10 July 2011

Townley, B. And Beech, N. (2010) Introduction to Part IV, in B. Townley and N.Beech (eds) Managing Creativity: Exploring the Paradox, Cambridge: CUP, 209-215.

Universities UK (2010) Creating Prosperity: the role of higher education in driving the UK's creative economy, http://www.universitiesuk.ac.uk/Publications/Pages/CreatingProsperitytheroleofhighereducati on.aspx accessed 25 March 2012

Vershinina, N., Barrett, R. and Meyer, M. (2011) Forms of capital, intra-ethnic variation and Polish entrepreneurs in Leicester Work, Employment and Society, 25(1): 101-117 